\title{
RATES OF RETURN ON OPEN-END DEBT INVESTMENT FUNDS \\ AND BANK DEPOSITS IN POLAND \\ IN THE YEARS 1995-2015 - A COMPARATIVE ANALYSIS
}

Iwona Dittmann, Ph.D.

Wroctaw University of Economics

Faculty of Economic Sciences

Department of Finance

Komandorska 118-120, 53-345 Wroctaw, Poland

e-mail:iwona.dittmann@ue.wroc.pl

Received 30 September 2015, Accepted 22 June 2016

\begin{abstract}
This paper presents the results of a comparison of the rates of return on specific open-end debt investment funds in Poland with the rates of return on bank deposits, in light of different time horizons. A comparative analysis was conducted based on the quartiles of the empirical distributions of the rates of return on selected funds and bank deposits. The empirical distributions were obtained using a moving window of observation. The results were largely influenced by very high interest rates on bank deposits in Poland in the years 1995-2001 (in the case of the oldest funds), and by the boom in the bond market in the years 2011-2012 (for the youngest funds). The investment horizon turned out to be significant. The best and worst funds were identified.
\end{abstract}

Keywords: personal finance, comparative analysis, open-end investment funds, deposits

JEL classification: D14, G11 


\section{Introduction}

This paper combines two research areas: financial markets and personal finance. After the pension reform in Poland, it is anticipated that pension benefits will be very low. Therefore, for several years, Polish people have been encouraged to independently save and invest in order to have additional money available once they are retired (see, e.g., Kowalczyk-Rólczyńska, Rólczyński, 2014). One of the ways in which to invest are open-end investment funds.

As in the case of saving in the form of bank deposits, investments in open-ended investment funds are possible even in the case of the possession of relatively small amounts of money (often the minimum amount is PLN 100-200). Investing in open-end investment funds is also not complicated from a technical point of view (shares of the fund can be purchased, e.g., in banks, over the phone, or on the internet). Saving in the form of a deposit is associated with a lower level of risk than investing in a fund. In this paper, the low financial barriers to entry, as well as the ease of conducting transactions proved decisive in the selection of open investment funds as an alternative to saving in the form of bank deposits. Debt funds were chosen due to the relatively low investment risks posed, as well as the expectation by investors of a risk premium. Money market funds are characterized by a lower level of risk, while mixed funds (i.e. stable and balanced growth) and equity funds exhibit a higher level of risk.

It is worth noting the differences between the calculation and prediction of rates of return for saving in the form of bank deposits and investing in open-end investment funds (OEFs). Deposits are established for a specified length of time, and at their renewal, there is the possibility of interest capitalization. There is no such possibility in the case of funds (excluding dividend funds). It should also be noted that when establishing a bank deposit, the rate of return is usually known in advance (i.e. in the case of a fixed interest rate). The rate of return on the investment when investing in a fund, however, is not known. For this reason, we can usually choose, exante, the best (in terms of interest rates) bank deposits available in the market, but cannot choose the best (in the sense of the future rate of return) fund.

Literature review is included in the first section of the paper. Data, assumptions, and methodology are described in the second section of the paper. The subsequent part contains the results of the comparative analysis of the rates of return which has been conducted. Discussion is in the last section. At the end of the article, box plots presenting empirical distributions of the rates of return are presented. 


\section{Literature review}

Personal finance and household finance are among the least explored areas of finance (Barembruch, 2012; Jajuga, 2013). Scientists and practitioners highlights, however, the importance of household finance and financial planning (e.g. Kawiński, 2015). They state that decisions taken by a person or a household may refer to a shorter or longer time horizon. The longterm decisions relate to investing, financing, and securing capital. The short-term decisions relate to management of financial liquidity: short-term investing and financing (see, e.g. Jajuga, 2013). Decisions of households aimed at saving and investing are studied in different aspects: 1) efficiency factors (e.g. Musiał, 2014a); 2) psychological aspects (e.g. Breuer et al., 2014; Brown, Taylor, 2014; Stango, Zinman, 2009; Musiał, 2012); 3) personal finance management rationality (e.g. Musiał, 2014b), 4) the meaning of financial literacy (e.g. Zdanowska, 2012); 5) downside risks (e.g. Jajuga, 2013; Solarz, 2010); 6) behavioural or Maslowian portfolio theory (e.g. Majewski, 2011; Majewski, 2014); 7) the diversification of the portfolio depending on the financial literacy and financial advice (e.g. Gaudecker, 2015; Musiał, 2012); 8) dynamics of household finance (e.g. Brown et al., 2015); 9) the role of financial advisers (e.g. Waliszewski, 2014; Sarnowski, 2012). Furthermore, National Bank of Poland quarterly publishes reports on the financial situation of the Polish households (Premik, Tyrowicz, 2016).

The subject of OEFs rentability or funds performance in Poland is often touched in scientific research (see, e.g.Zamojska, 2015; Miziołek, 2015; Karpio, Żebrowska-Suchodolska,2015; Kopiński, Porębski, 2014; Perez, 2014; Jurek-Wasilewska, 2014; Karkowska, Niewińska, 2013; Karpio, Żebrowska-Suchodolska, 2013; Jamróz, 2013; Perez, 2012; Dawidowicz, 2012; Zamojska, 2012; Perez, 2011; Kompa, Witkowska, 2010; Zamojska, 2008). However, research is carried out usually in terms of efficiency of fund management than from the point of view of the investor. In this paper, the point of view of the investor has been adopted.

Comparisons of the profitability and risk of saving and investing in various assets (mutual funds, stocks, bonds, real estate, etc.) are a frequent subject of analyses published on financial portals (e.g. analizy.pl, bankier.pl, mojaprzyszlaemerytura.pl, open.pl), and in economic journals (e.g. "Rzeczpospolita"). Comparative analyses on the rates of return on deposits and investment funds, however, are usually simplified. For example, the capitalization of interest in the case of the renewal of deposits within longer-term investment horizons is not considered, and distribution fees for funds are also not taken into account. In addition, comparisons often refer to average (and sometimes minimum or maximum) returns on the funds and to the average interest rate on deposits. Research rarely involve longer-term horizons, usually they relate to the 
previous quarter or year (see, e.g. Sytuacja..., 2016; Peć, 2012). In this paper, the assumptions which have been made are more realistic.

In my opinion, there is a lack of research from the investor point of view, in particular in comparative terms and in different investment horizons.

The aim of the study is to answer three research questions: 1) whether investing in units of open-end debt investment funds was more attractive (the rate of return was higher) than saving in the form of a bank deposit; 2) whether the attractiveness of the selected option was depended on the investment horizon; 3) whether exceptionally good or exceptionally bad funds, compared with deposits, can be identified.

\section{Data and methodology}

Currently in Poland, there are 56 open-end investment funds which invest in debt securities. The largest group among these is Polish universal debt funds (25). In addition, there are eleven Polish Treasury securities funds, eight Polish corporate debt funds, two European universal debt funds, two global corporate debt funds, two other global debt funds, one global universal debt fund, two US universal debt funds, two remaining foreign debt funds, and one remaining Polish debt fund. ${ }^{1}$ The present study involved the two largest groups of debt funds - universal Polish funds and Polish Treasury securities funds. Among them, the funds that have been in existence for less than five years have been rejected. The final analysis includes 20 funds: 14 universal Polish funds (U) and six Polish Treasury securities funds (T).

To calculate the rates of return on the investment funds, the monthly quotations of the shares of individual funds (as of the $29^{\text {th }}$ of each month) ${ }^{2}$ were used. To calculate the rates of return on bank deposits for specific periods, monthly data from the Polish National Bank (www. nbp.pl) regarding the average interest rate on 1-year deposits was relied upon. This interest rate was increased by $20 \%$. On the basis of the preliminary analysis conducted, it was found that the establishment of a deposit with an annual interest rate surpassing the average annual interest rate by $20 \%$ was, and continues to be, possible. The investor, at the moment of investing, could select a deposit with one of the highest interest rates on the market. These interest rates were significantly higher than the average rate.

\footnotetext{
1 Division by Analizy Online, www.analizy.pl.

2 www.stooq.pl.
} 
The research period varied for the individual funds - the analysis included quotations from the month of the fund's establishment until February of $2015 .{ }^{3}$ In the case of deposits, the research time periods adopted corresponded to the time periods of functioning of the individual funds.

Banks offer deposits of various maturities. Annual deposits were chosen for the study. The study included the 1-year capitalization of interest for deposits and no capitalization of interest for funds when calculating holding period returns. In the case of deposits, first, the holding period return over a given period of investment was calculated (assuming a renewal of the deposit after each 12 months). The holding period return was then divided by the number of years to give the simple annualized rate of return (Formula 1). This formula of annualized return is one of the formulas proposed by Jajuga (2014). ${ }^{4}$

$$
R_{D}=\frac{\text { holding period return }}{n}=\frac{\left(1+r_{1}\right) \times\left(1+r_{2}\right) \times \ldots \times\left(1+r_{n}\right)-1}{n}=\frac{\prod_{i=1}^{n}\left(1+r_{i}\right)-1}{n}
$$

where:

$R_{D}-$ simple annualized net rate of return on deposit,

$r_{i}-$ net (after tax) interest rate on 1-year deposit in the "i" year,

$n-$ investment horizon in years.

In the case of investments in funds, analogously the holding period return was divided by the number of years. Moreover, in the case of funds, distribution fees were included. The maximum rates were adopted for each fund, according to the applicable prospectuses (as of February 2015). The rates of return calculated were net rates of return, that is, they included capital gains tax (from the point at which it began to apply). It was noted that the distribution fees reduced the taxable base (Skrobosz, 2014) (Formula 2).

$$
R_{F}=\frac{\text { holding period return }}{n}=\frac{\left[\frac{Q_{S}}{Q_{B}} \times(1-P)-1\right] \times(1-T)}{n}
$$

where:

$$
R_{F}-\text { simple annualized net rate of return on a fund, }
$$

\footnotetext{
3 The longest research period in the study covered months: June 1995-February 2015, the shortest: May 2007-February 2015.

4 Jajuga (2014) indicates three possibilities of calculating the annualized rate of return depending on the assumptions adopted for the period of capitalization: simple rate of return, effective rate of return, and log return. In this study, simple rate of return has been adopted (the choice was dictated by the fact that in the case of funds, there is no capitalization of interest during the investment period).
} 
$Q_{S}$ - quotation on the day of the sale of shares by investor,

$Q_{B}$ - quotation on the day of the buy of shares by investor,

$P \quad-$ distribution fee rate $(\%)$,

$T-$ capital gains tax rate $(\%)$,

$n-$ investment horizon in years.

The study, conducted to answer the aforementioned questions, ran the following course: ${ }^{5}$ for each of the funds included in the study, the net annualized rates of return were calculated through the use of a rolling window of observation with a shift of one month (monthly data was used). The length of the observation window was equal to the investment horizon. By changing the length of the moving observation window and repeating the procedure, an empirical distribution of the rates of return for different investment horizons was obtained. The present study adopted different lengths of investment horizons - from 1 year to 19 years, ${ }^{6}$ $h \in(1,2, \ldots, 19$ years $)$. In the same way, the distribution of the net rates of return on bank deposits was prepared.

Among the various distribution parameters (modal, percentiles), which may serve as a criterion of evaluation, the quartiles of the rates of return $\left(Q_{1}, Q_{2}, Q_{3}\right)$ were used in the present study. They were selected because of the importance of the information they provide for the investor. The first quartile, $\mathrm{Q}_{1}$, can be interpreted in the following manner: the chances of the investor obtaining a rate of return lower than the value of the quartile are $25 \%$, and the chances of achieving a higher rate of return are $75 \%$. It can be assumed that the value of this quartile will be of great importance for a risk-averse investor. The median $\left(\mathrm{Q}_{2}\right)$ indicates that the chances of getting returns both lower and higher than the median are the same, and amount to $50 \%$. It can be recognized that the investor for whom risk is of neutral concern will assign the most importance to this variable. The third quartile, $Q_{3}$, is the value of the rate of return for which the chances of exceeding it are $25 \%$, and the chances of not exceeding it (of failure to achieve it) $75 \%$. This quartile will interest the investor who is prone to taking risks. The box plots which have been prepared also make it possible to analyze the range of not outliersand to identify outlying and extreme observations.

\footnotetext{
5 To the best knowledge of the author, in the scientific literature so far there have been no comparisons making use of the methodology which has been adopted in the present paper.

${ }^{6}$ The longest horizon adopted resulted from the date of establishment of the first open investment fund debt.
} 


\section{The results of the study}

The number of observations (i.e. net annual rates of return), on the basis of which the empirical distributions of the rates of return for different investment horizons were determined, and on the basis of which the box plots were prepared (Figures 2-6 included at the end of the paper), are shown in Table 1 (at the end of the paper).

Due to the different dates of fund foundation (see Table 1), three groups were isolated: the oldest funds (established in 1995-1998), the group of funds established in 1999, and the youngest group of funds (established in 2001-2007).

The first Polish open-ended debt investment fund was Pioneer Obligacji Plus (U), founded in June 1995. Having adopted the criterion of the median rates of return, $Q_{2}$, it can be concluded that for investment horizons from 1 to 8 years, the median of the rates of return on the fund was slightly higher than the median of the rates of return on deposits. For longer investment horizons, the median of the rates of return on deposits was higher than the median of the rates of return on the fund (differences from insignificant to approx. 5 percentage points). When adopting the first quartile of the rates of return, $\mathrm{Q}_{1}$, as the criterion, a slight advantage of deposits over funds can be observed. The advantage of deposits over funds appears again for $\mathrm{h} \geq 14$ (from 2.5 percentage points to 5 percentage points). For the remaining investment time horizons, the differences (in favor of the fund) are minimal - a maximum of approx. 1.25 percentage points. When utilizing the third quartile of the rates of return, $\mathrm{Q}_{3}$, the clear superiority of deposits, regardless of the length of the time horizon, should be noted. $\mathrm{Q}_{3}$ assumes values which are around 4.25 to over 5 percentage points higher in the case of bank deposits.

An analysis of the distribution of the rates of return of the funds founded in 1998 indicates a distinct difference among them. In the case of Investor Obligacji (U), for each investment horizon the median of the rates of return on the fund was higher than the median on the rates of return on deposits (from insignificant to 4 percentage points). In the case of Skarbiec Depozytowy $(\mathrm{U})$, the median of the rates of return on the fund was higher for $h \leq 10$. Assuming the criterion $\mathrm{Q}_{1}$, it can be concluded that in the case of Investor Obligacji, the value of this quartile of the rates of return on deposits was higher (usually by 1.5 percentage points) than the quartile of the rates of return on the fund. However, in the case of Skarbiec Depozytowy, the value of the quartile of the rates of return on the fund was usually higher (besides $h=1,2,15,16$ ). Utilizing the third quartile $\mathrm{Q}_{3}$ as the criterion, the superiority of deposits over the funds can be determined in the case of both funds (as well as for Pioneer Obligacji Plus). 
The next (quite varied) group is made up of seven funds (4 universal funds and 3 treasury funds) founded in 1999. The best funds in this group are: UniKorona Obligacje (U), BPH Obligacji 1 (U), and PZU Papierów Dłużnych POLONEZ (U). In the case of UniKorona Obligacje (U), all of the quartiles of the rates of return on the funds, for every investment horizon, assumed higher values than those found in the case of deposits. In the case of PZU Papierów Dłużnych POLONEZ, deposits are better only when using $\mathrm{Q}_{1}$ as the criterion and along with $\mathrm{h} \leq 6$. In the case of BPH Obligacje $1(\mathrm{U})$, deposits are better when utilizing $\mathrm{Q}_{1}$ as well as $\mathrm{h} \leq 4$, and also when using the median as the criterion, and here for $\mathrm{h}=1,2,3,13,15$. The last of the universal funds, PKO Obligacje (U), ranks between the funds above and the three treasury funds. The median of the rates of return was almost always higher (except for $h=1,2$ ), however, the differences were not great. Assuming the criterion $\mathrm{Q}_{1}$, it can be concluded that the deposit was better in the case of investment horizons of $\mathrm{h} \leq 7$, and worse for longer investment horizons, that is $h \geq 12$. When adopting the criterion $\mathrm{Q}_{3}$, it can be determined that the fund was better in the case of investment horizons $\mathrm{h} \leq 6$, while in the case of longer time horizons, it was slightly worse than deposits. Among the best treasury funds was ING Obligacji. For most investment horizons, the median of the rates of return on deposits assumed similar values to the median of the rates of return on the fund. When adopting $\mathrm{Q}_{1}$ as the criterion, the advantage of the fund over the deposit in the case of longer time horizons $(\mathrm{h}=10, \ldots, 14)$ can be found; for the remaining time horizons the values of the quartile were slightly lower than those found in the case of deposits, or close to them. When adopting the criterion $\mathrm{Q}_{3}$, it can be concluded that there was a slight advantage of the fund in the case of shorter time horizons $(\mathrm{h}=2, \ldots$, 6). In the case of the remaining treasury funds (Legg Mason Obligacji and Skarbiec Obligacje Instrumentów Dłużnych), the median indicated the superiority of the deposits or displayed similar levels for both funds and deposits, regardless of the investment horizon. When adopting $\mathrm{Q}_{1}$ as the criterion, the advantage of the deposits over the funds can be found no matter what the investment horizon. Only when adopting the third quartile $\mathrm{Q}_{3}$ as the criterion, and only for shorter time horizons (up to five years), can higher values in the case of funds be observed.

The group of the youngest funds consists of nine funds which were founded in the years 2001-2007. These include: KBC Papierów Dłużnych (U), Aviva Investors Obligacji (S), Arka BZ WBK Obligacji Skarbowych (S), Novo Papierów Dłużnych (U), MetLife Obligacji Skarbowych (S), BPH Obligacji 2 (U), PKO Obligacji Długoterminowych (U), Opera Avista. pl (U), SKOK Obligacji (U), and PKO Papierów Dłużnych Plus (U). When adopting the median as a criterion, it can be concluded that in the case of five funds - the three youngest, founded in 2007, and PKO Obligacji Długoterminowych (2005), and Arka BZ WBK Obligacji 
Skarbowych (2002) - the median of the rates of return on the funds assumed a higher value for every investment horizon. The difference was smallest for $h=1$, for longer investment horizons it reached almost 4 percentage points. In the case of the remaining funds, the median assumed higher values for the distribution of the rates of return on deposits for $\mathrm{h}=1$, sometimes for $\mathrm{h}=2$ (the difference did not exceed 2 percentage points). In the case of longer investment horizons, the median indicated the superiority of the funds over deposits (from an insignificant difference to 2 percentage points, in the case of one fund, the difference exceptionally reached almost 4 percentage points). The exceptional fund turned out to be Novo Papierów Dłużnych. The median of the rates of return on this fund, for almost every investment horizon (except for $\mathrm{h}=2$ ) was lower than the median of the rates of return on deposits. When assuming the criterion $\mathrm{Q}_{1}$, it can be observed that in the case of shorter investment horizons, from $\mathrm{h}=1$ to $\mathrm{h}=4$, depending on the fund (exceptionally, in the case of $\mathrm{KBC}$ from $\mathrm{h}=1$ to $\mathrm{h}=8$ ), there occurred either a slight predominance of the deposit (usually for $\mathrm{h}=1$ ), or similar quartile values. For the longest horizons (most frequently from $\mathrm{h}=5$, but in the case of Arka BZ WBK, PKO Obligacji Długoterminowych, and PKO Papierów Dłużnych Plus - from $h=2$ ), $\mathrm{Q}_{1}$ was higher in the case of funds. The exception is Novo Papierów Dłużnych. The first quartile $\mathrm{Q}_{1}$ of the rates of return on this fund were always lower than $\mathrm{Q}_{1}$ of the rates of return on deposits (the differences were quite substantial, even 3 percentage points). When assuming $\mathrm{Q}_{3}$ as the criterion, a clear dominance of funds over deposits, for all investment horizons, can be discerned (in the case of the funds founded in 2001-2004, usually around 1-2 percentage points difference, in the case of the funds founded in 2005-2007, even 4 percentage points). The exception is, again, Novo Papierów Dłużnych, in the case of which for $h \geq 5 \mathrm{Q}_{3}$ rates of return are lower than the $\mathrm{Q}_{3}$ rates of return on deposits.

To sum up, it can be stated that in the case of investment time periods which included (in whole or in part) the years between 1995-2001, the choice of a fund often turned out to be the poorer choice. This is especially evident in the case of the analysis conducted on the oldest funds. In the case of the funds which were founded in 2005 and 2007 (that is, the youngest analyzed group), the results of the study are diametrically different - there is a clear preponderance of funds over deposits, especially in the case of longer investment time horizons, characteristic for developed financial markets.

The investment horizon as well as the attitude of the investor towards risk (made evident by the choice of the adequate quartile as a criterion) had a great deal of significance. When adopting $\mathrm{Q}_{1}$ as the criterion, in the case of the shortest, 1-year investment horizon, the deposit was almost always a better choice than a fund. Also, for the investment horizons which lasted 
several years - and in even in the case of some which lasted over a dozen years - the first quartile of the distribution of the rates of return on the deposits often assumed higher values (besides the group of the youngest funds). In the case of taking the median as the comparative criterion, for the shortest, i.e. 1- and 2-year investment horizons, either the deposit or the fund was found to be the better choice. Thus, the choice of fund was significant. In the case of longer investment horizons, except for a few funds, the better choice turned out to be the fund. $\mathrm{Q}_{3}$, except for the distributions of the rates of return for the oldest universal funds, as well as the oldest Polish Treasury funds (for longer time horizons), indicates the dominance of funds over deposits.

The analysis enabled an indication of the best and the worst funds. The following funds should be considered as exceptionally poor in their group (when compared to deposits): Investor Obligacji (U), for which all quartiles, regardless of the investment horizon, indicated the superiority of deposits, and Novo Papierów Dłużnych (U), in which case the quartiles almost always indicated that deposits were more advantageous. On the other hand, some funds differentiate themselves positively, such as UniKorona Obligacje (U) and ING Obligacji Treasury fund. The distribution of the rates of return on the UniKorona Obligacje fund were worse than the analogous rates of return on deposits only when taking into account $\mathrm{Q}_{1}$ as the criterion, and, at the same time, assuming a 1- or 2-year investment horizon. ING Obligacje, however, is much better at competing with deposits than the other two Treasury funds in this group, especially when adopting the median as the criterion.

\section{Discussion}

The difference in the rate of return between debt OEF and deposits results from the difference in risk level. As it was formulated in the introduction, debt funds were chosen due to the relatively low investment risks posed, the reforebig differences in returns between those two were not expected.

It is worth emphasizing that caution should be exercised in formulating conclusions surrounding the future on the basis of the results obtained. A large impact was made upon a part of the results by the very high interest rates on bank deposits in the years 1995-2001 (Figure 1).

They were significant in the comparative analysis of the rates of return conducted for the funds which were operating in those years. In the case of these funds, retrospective regularities should not be adopted as prospective regularities. In contrast, the results of the analyses conducted on the youngest funds were in large part shaped by the boom in the bond market in the years 2011-2012. For this reason, they also should not be used for the purpose of predicting 
differences between the rate of return on a fund and the rate of return on a bank deposit in a naïve manner. The importance of the existence of structural changes in a series of rates of return on financial instruments in the context of selecting the appropriate length of time as a sample for the purposes of modeling and predicting is pointed out, inter alia, by Doman and Doman (2009). The problem of the lack of the theory delimiting the optimal length of time for the analyzed sample in the case of the financial market, as well as the attendant implications, is touched upon by, inter alia, Zamojska (2012). In turn, Marcinkowski (2009) emphasizes that, even in the case of very long investment horizons, the rate of return which is realized can greatly vary from the rate of return estimated on the basis of historical data spanning decades. ${ }^{7}$

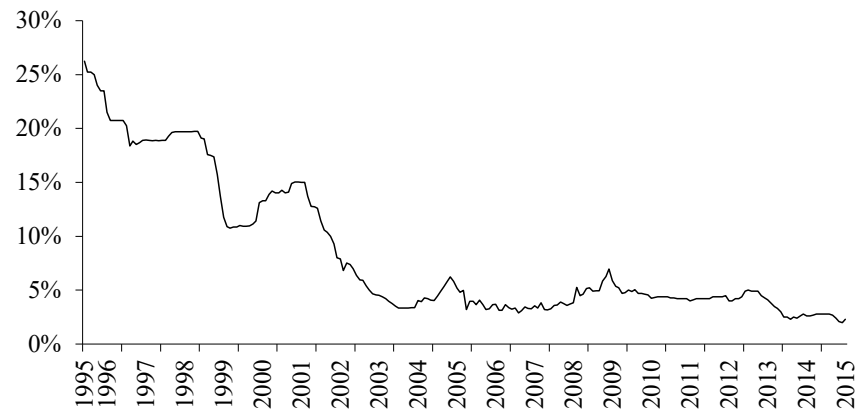

Figure 1. Average interest rates on 1-year bank deposits in the period June 1995-February 2015 Source: own elaboration on the basis of data fromNBP (www.nbp.pl).

Further studies aimed at determining a risk premium for investing in debt OEF compared with savings on deposit, appear to be justified.The adoption of interest rates on deposits as the risk-free rate (rather than the interest rate on treasury bonds) seems to be reasonable for the needs of the household finances. Also, it seems worth determining the investment horizon guarantees in the past achieving returns on $\mathrm{OEF}$, higher than deposit rates.

\footnotetext{
${ }^{7}$ It is worth noting that the empirical distributions of returns included in the paper, show, among others, historical ranges of the rates of return for a given investment horizon.
} 
Table 1. The number of observations (i.e. net annualized rates of return), on the basis of which the empirical distributions of the rates of return for different investment horizons were determined, and on the basis of which the box plots were prepared

\begin{tabular}{|c|c|c|c|c|c|c|c|c|c|c|c|c|c|c|c|c|c|c|c|c|}
\hline \multirow{2}{*}{$\begin{array}{l}\text { Establishe- } \\
\text { ment date }\end{array}$} & \multirow{2}{*}{ Funds } & \multicolumn{19}{|c|}{ Investment horizons in years } \\
\hline & & 1 & 2 & 3 & 4 & 5 & 6 & 7 & 8 & 9 & 10 & 11 & 12 & 13 & 14 & 15 & 16 & 17 & 18 & 19 \\
\hline $1995-06-30$ & $\begin{array}{l}\text { Pioneer Obligacji Plus } \\
\text { (Pioneer FIO) }\end{array}$ & 225 & 213 & 201 & 189 & 177 & 165 & 153 & 141 & 129 & 117 & 105 & 93 & 81 & 69 & 57 & 45 & 33 & 21 & 9 \\
\hline 1998-01-30 & $\begin{array}{l}\text { Investor Obligacji } \\
\text { (Investor FIO) }\end{array}$ & 194 & 182 & 170 & 158 & 146 & 134 & 122 & 110 & 98 & 86 & 74 & 62 & 50 & 38 & 26 & 14 & 2 & - & - \\
\hline 1998-03-31 & $\begin{array}{l}\text { Skarbiec Depozytowy DPW } \\
\text { (Skarbiec FIO) }\end{array}$ & 192 & 180 & 168 & 156 & 144 & 132 & 120 & 108 & 96 & 84 & 72 & 60 & 48 & 36 & 24 & 12 & - & - & - \\
\hline 1999-01-29 & $\begin{array}{l}\text { Legg Mason Obligacji } \\
\text { (Legg Mason Parasol FIO) }\end{array}$ & 182 & 170 & 158 & 146 & 134 & 122 & 110 & 98 & 86 & 74 & 62 & 50 & 38 & 26 & 14 & 2 & - & - & - \\
\hline 1999-02-26 & $\begin{array}{l}\text { ING Obligacji } \\
\text { (ING FIO) }\end{array}$ & 181 & 169 & 157 & 145 & 133 & 121 & 109 & 97 & 85 & 73 & 61 & 49 & 37 & 25 & 13 & 1 & - & - & - \\
\hline 1999-04-30 & $\begin{array}{l}\text { Skarbiec Obligacja Instrumentów } \\
\text { Dłużnych } \\
\text { (Skarbiec FIO) }\end{array}$ & 179 & 167 & 155 & 143 & 131 & 119 & 107 & 95 & 83 & 71 & 59 & 47 & 35 & 23 & 11 & - & - & - & - \\
\hline $1999-07-30$ & $\begin{array}{l}\text { PKO Obligacji } \\
\text { (Parasolowy FIO) }\end{array}$ & 176 & 164 & 152 & 140 & 128 & 116 & 104 & 92 & 80 & 68 & 56 & 44 & 32 & 20 & 8 & - & - & - & - \\
\hline 1999-08-31 & $\begin{array}{l}\text { BPH Obligacji } 1 \\
\text { (BPH FIO Parasolowy) }\end{array}$ & 175 & 163 & 151 & 139 & 127 & 115 & 103 & 91 & 79 & 67 & 55 & 43 & 31 & 19 & 7 & - & - & - & - \\
\hline 1999-09-30 & $\begin{array}{l}\text { UniKorona Obligacje } \\
\text { (UniFundusze FIO) }\end{array}$ & 174 & 162 & 150 & 138 & 126 & 114 & 102 & 90 & 78 & 66 & 54 & 42 & 30 & 18 & 6 & - & - & - & - \\
\hline 1999-10-29 & $\begin{array}{l}\text { PZU Papierów Dłużnych POLONEZ } \\
\text { (PZU FIO Parasolowy) }\end{array}$ & 173 & 161 & 149 & 137 & 125 & 113 & 101 & 89 & 77 & 65 & 53 & 41 & 29 & 17 & 5 & - & - & - & - \\
\hline $2001-12-31$ & $\begin{array}{l}\text { KBC Papierów Dłużnych } \\
\text { (KBC FIO) }\end{array}$ & 147 & 135 & 123 & 111 & 99 & 87 & 75 & 63 & 51 & 39 & 27 & 15 & 3 & - & - & - & - & - & - \\
\hline 2002-04-30 & $\begin{array}{l}\text { Aviva Investors Obligacji } \\
\text { (Aviva Investors FIO) }\end{array}$ & 143 & 131 & 119 & 107 & 95 & 83 & 71 & 59 & 47 & 35 & 23 & 11 & - & - & - & - & - & - & - \\
\hline 2002-08-30 & $\begin{array}{l}\text { Arka BZ WBK Obligacji Skarbowych } \\
\text { (Arka BZ WBK FIO) }\end{array}$ & 139 & 127 & 115 & 103 & 91 & 79 & 67 & 55 & 43 & 31 & 19 & 7 & - & - & - & - & - & - & - \\
\hline 2003-06-30 & $\begin{array}{l}\text { Novo Papierów Dłużnych } \\
\text { (Novo FIO) }\end{array}$ & 129 & 117 & 105 & 93 & 81 & 69 & 57 & 45 & 33 & 21 & 9 & - & - & - & - & - & - & - & - \\
\hline 2004-06-30 & $\begin{array}{l}\text { MetLife Obligacji Skarbowych } \\
\text { (Krajowy FIO) }\end{array}$ & 117 & 105 & 93 & 81 & 69 & 57 & 45 & 33 & 21 & 9 & - & - & - & - & - & - & - & - & - \\
\hline 2005-08-31 & $\begin{array}{l}\text { BPH Obligacji } 2 \\
\text { (BPH FIO Parasolowy) }\end{array}$ & 103 & 91 & 79 & 67 & 55 & 43 & 31 & 19 & 7 & - & - & - & - & - & - & - & - & - & - \\
\hline $2005-12-30$ & $\begin{array}{l}\text { PKO Obligacji Długoterminowych } \\
\text { (Parasolowy FIO) }\end{array}$ & 99 & 87 & 75 & 63 & 51 & 39 & 27 & 15 & 3 & - & - & - & - & - & - & - & - & - & - \\
\hline $2007-02-28$ & $\begin{array}{l}\text { Opera Avista.pl } \\
\text { (Opera FIO) }\end{array}$ & 85 & 73 & 61 & 49 & 37 & 25 & 13 & 1 & - & - & - & - & - & - & - & - & - & - & - \\
\hline $2007-05-31$ & $\begin{array}{l}\text { PKO Papierów Dłużnych Plus } \\
\text { (Parasolowy FIO) }\end{array}$ & 82 & 70 & 58 & 46 & 34 & 22 & 10 & - & - & - & - & - & - & - & - & - & - & - & - \\
\hline $2007-05-31$ & $\begin{array}{l}\text { SKOK Obligacji } \\
\text { (SKOK PARASOL FIO) }\end{array}$ & 82 & 70 & 58 & 46 & 34 & 22 & 10 & - & - & - & - & - & - & - & - & - & - & - & 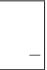 \\
\hline
\end{tabular}

Source: own elaboration. 


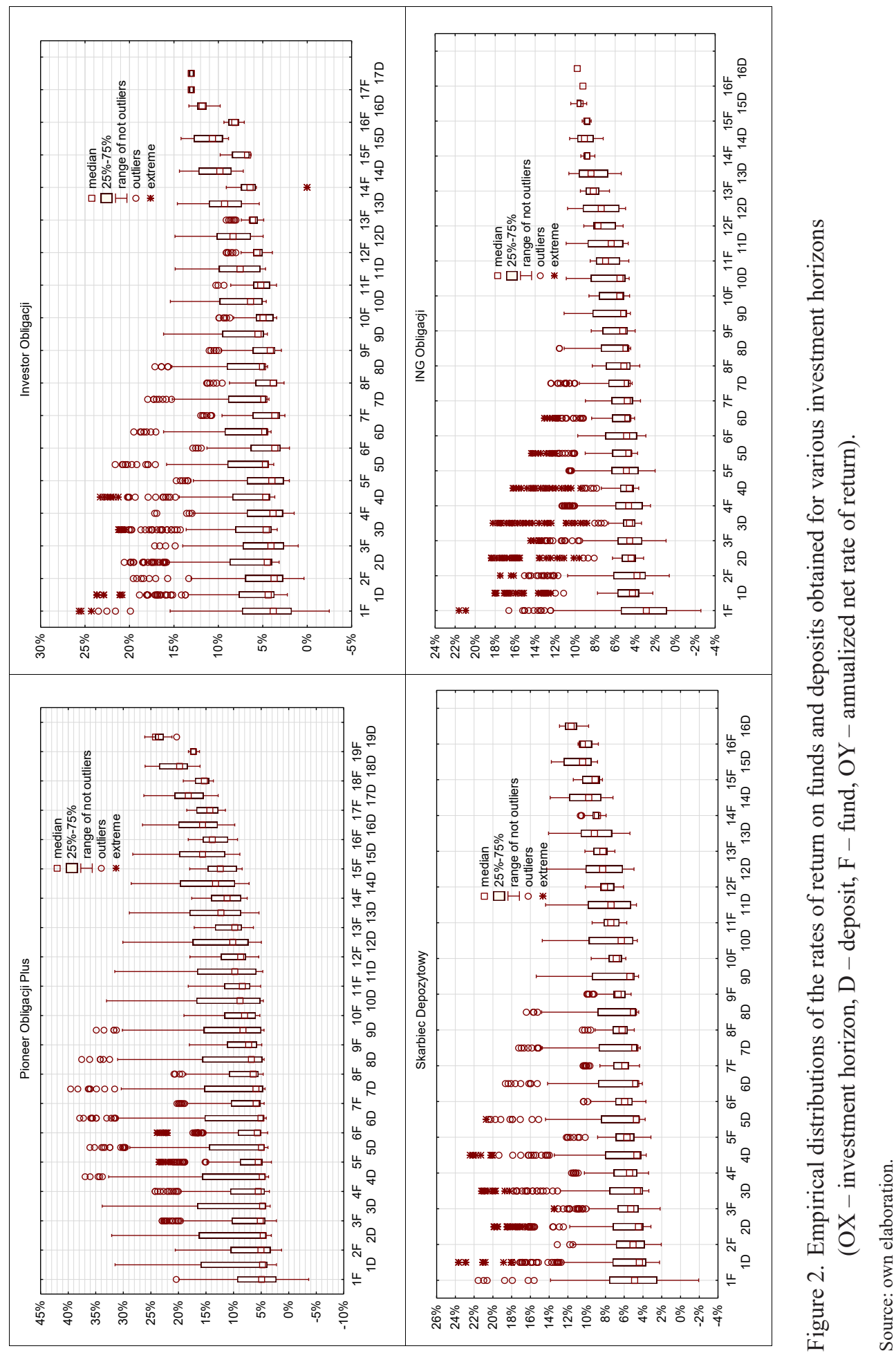




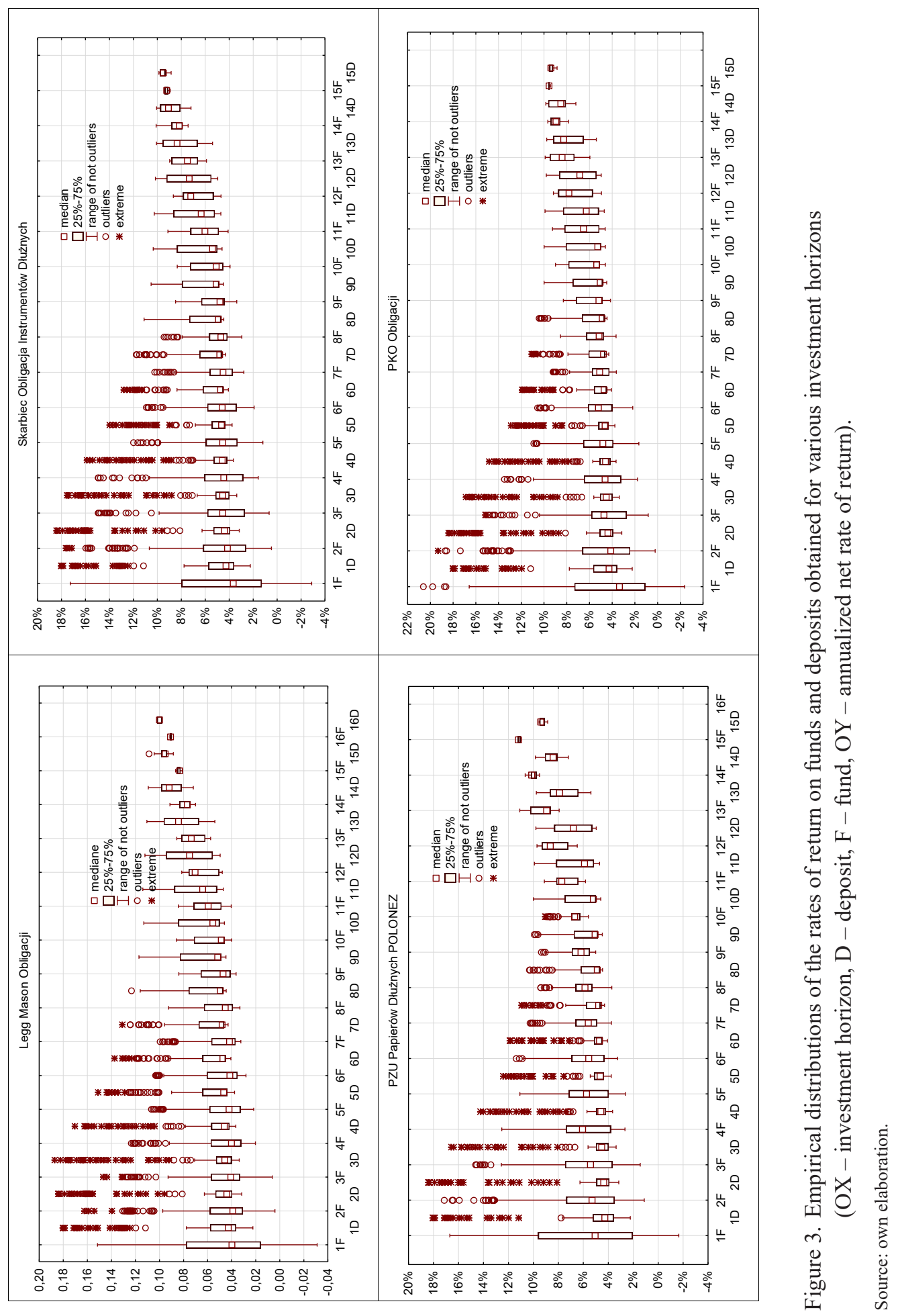




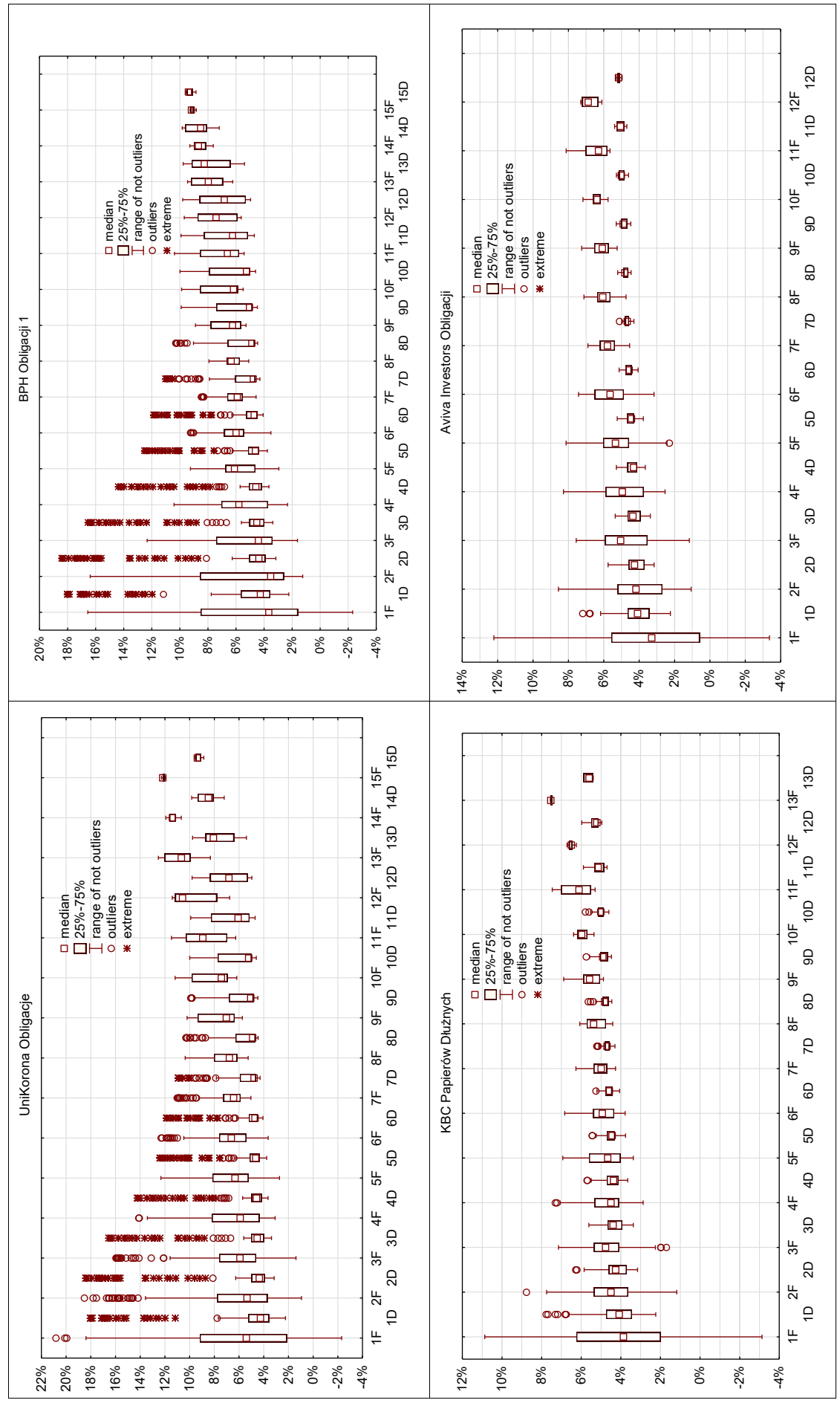



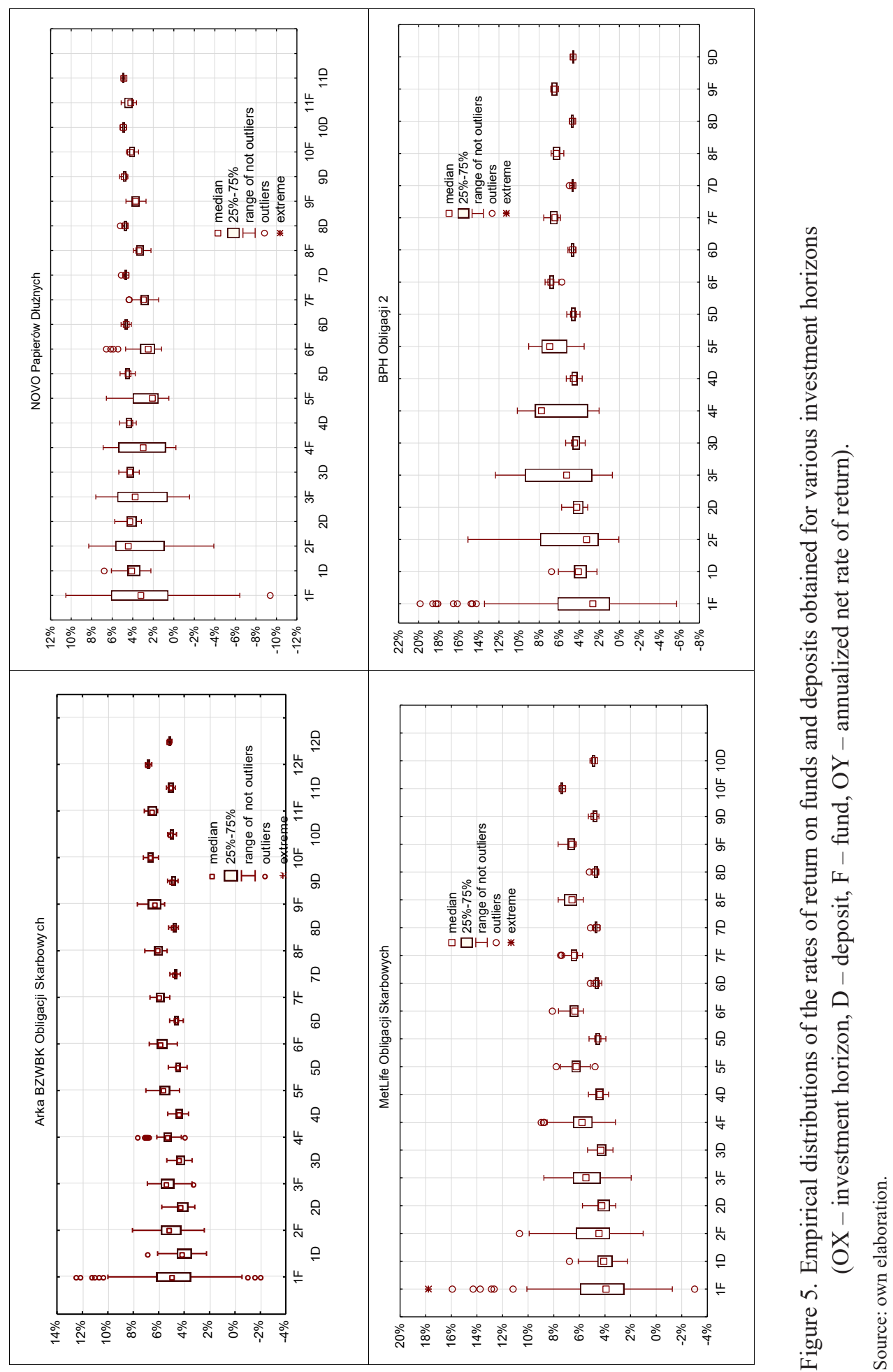


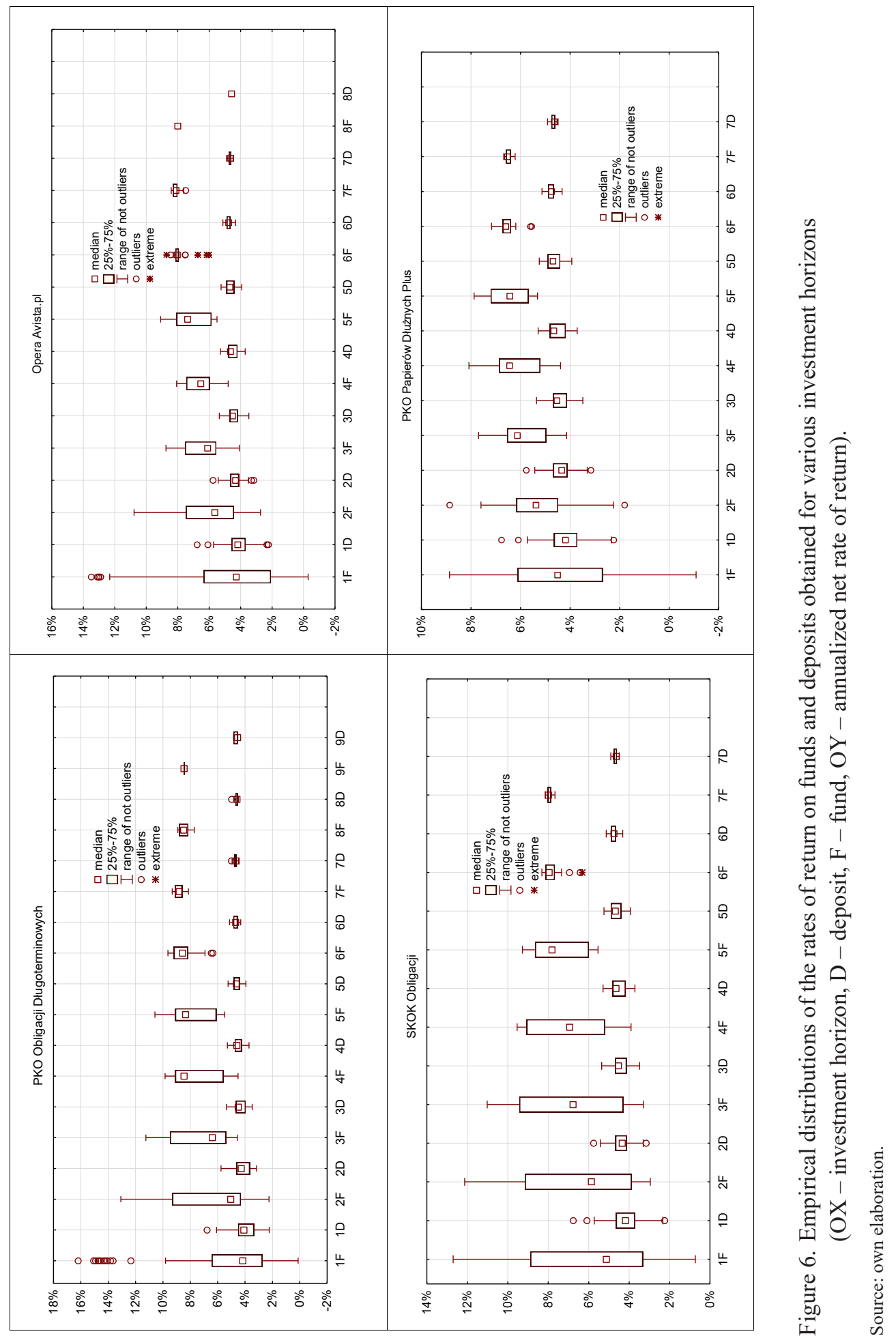




\section{References}

Barembruch, A. (2012). Zarządzanie finansami osobistymi - teoria i praktyka. Finanse, Rynki Finansowe, Ubezpieczenia, 689 (50), 239-248.

Breuer, W., Riesener, M., Salzmann, A.J. (2014). Risk aversion vs. individualism: what drives risk taking in household finance? The European Journal of Finance, 20 (5), 446-462. DOI: 10.1080/1351847X.2012.714792.

Brown, S., Ghoshb, P., Su, L., Taylor, K. (2015). Modelling household finances: A Bayesian approach to a multivariate two-part model. Journal of Empirical Finance, 33 (September), 190-207. DOI: 10.1016/j.jempfin.2015.03.017.

Brown, S., Taylor, K. (2014). Household finances and the 'Big Five' personality traits. Journal of Economic Psychology, 45 (December), 197-212. DOI: 10.1016/j.joep.2014.10.006.

Dawidowicz, D. (2012). Efektywność nowych funduszy inwestycyjnych-analiza porównawcza. In: J Harasim, J. Cichy (eds.) Finanse $w$ niestabilnym otoczeniu - dylematy $i$ wyzwania. Rynki finansowe (pp. 369-379). Katowice: Wydawnictwo Uniwersytetu Ekonomicznego w Katowicach.

Doman, M., Doman, R. (2009). Modelowanie zmienności i ryzyka: metody ekonometrii finansowej. Kraków: Oficyna a Wolters Kluwer business.

Gaudecker, H.-M.V. (2015). How Does Household Portfolio Diversification Vary with Financial Literacy and Financial Advice? The Journal of Finance, 70 (2), 489-507. DOI: 10.1111/ jofi.12231.

Homa, M., Mościbrodzka, M. (2016). Dynamiczne wersje hybrydowych modeli market timing oraz weryfikacja ich przydatności w ocenie ryzyka i efektywności funduszy inwestycyjnych. Finanse, Rynki Finansowe, Ubezpieczenia, 79, 73-85. DOI: 10.18276/ frfu.2016.79-05.

Jajuga, K. (2013). Ryzyko inwestycji gospodarstwa domowego - koncepcja pomiaru. In: K. Marcinek (eds.), Inwestycje i nieruchomości we współczesnej gospodarce (pp. 151-163). Katowice: Wydawnictwo Uniwersytetu Ekonomicznego w Katowicach.

Jajuga, K., Jajuga, T. (2014). Inwestycje: instrumenty finansowe, aktywa niefinansowe, ryzyko finansowe, inżynieria finansowa. Warszawa: Wydawnictwo Naukowe PWN.

Jamróz, P. (2013). Efektywność wybranych FIO rynku akcji w latach 2003-2011. Finanse, Rynki Finansowe, Ubezpieczenia, 63, 193-206.

Jurek-Wasilewska, K. (2014). Efektywność inwestowania w otwartych funduszach inwestycyjnych w Polsce w latach 2001-2010. Finanse i Prawo Finansowe, 1 (1), 20-33.

Karkowska, R., Niewińska, K. (2013). Analiza zmienności stóp zwrotu funduszy inwestycyjnych w Polsce. Zarzadzanie i finanse, 11 (1/1), 255-267. 
Karpio, A., Żebrowska-Suchodolska, D. (2015). Badanie stabilności wyników funduszy inwestycyjnych przy użyciu miar efektywności opartych na współczynniku Sharpe’a. Finanse, Rynki Finansowe, Ubezpieczenia, 75, 221-231. DOI: 10.18276/frfu.2015.75-18.

Karpio, A., Żebrowska-Suchodolska, D. (2013). Porównanie efektywności inwestycyjnej FIO z wykorzystaniem information ratio i wskaźnika Sortino. Finanse, Rynki Finansowe, Ubezpieczenia, 63, 221-232.

Kawiński, M. (2015). Przegląd teorii finansów gospodarstw domowych w kontekście współczesnych uwarunkowań polityki publicznej. Studia z Polityki Publicznej, 1, 9-27

Kompa, K., Witkowska, D. (2010). Porównanie efektywności wybranych otwartych funduszy inwestycyjnych w okresie hossy i bessy. Acta Scientiarum Polonorum Oeconomia, 9 (3), 169-180.

Kowalczyk-Rólczyńska, P., Rólczyński, T. (2014). Odwrócony kredyt hipoteczny - dodatkowe źródło zabezpieczenia emerytalnego. Wiadomości Ubezpieczeniowe, 3, 133-147.

Kopiński, A., Porębski D. (2014). Weryfikacja modelu oceny efektywności funduszy inwestycyjnych. Finanse, Rynki Finansowe, Ubezpieczenia, 65, 353-361.

Majewski, S. (2011). Methodological Aspects of Behavioural Portfolio with Multitasking. Folia Oeconomica Stetinensia, 24-33, DOI: 10.2478/v10031-010-0008-4.

Majewski, S. (2014). The Maslowian Portfolio Theory Versus the Pyramid Portfolio. Folia Oeconomica Stetinensia, 14 (1), 91-101, DOI: 10.2478/foli-2014-0107.

Marcinkowski, J. (2009). Ryzyko, jakość prognoz a efektywność inwestowania na rynkach finansowych. Poznań: Wydawnictwo Uniwersytetu Ekonomicznego.

Miziołek, T. (2015). Wskaźnik activeshare na rynku akcyjnych funduszy inwestycyjnych w Polsce. Finanse, Rynki Finansowe, Ubezpieczenia, 75, 343-354. DOI: 10.18276/ frfu.2015.75-28.

Musiał, B. (2012). Memetyka w finansach osobistych. Problemy Zarządzania, Finansów i Marketingu, 21, 175-185.

Musiał, M. (2014a). Determinanty efektywności gospodarowania finansami osobistymi. In: B. Świecka (ed.), Współczesne problemy finansów osobistych (pp. 33-58). Warszawa: CeDeWu.pl.

Musiał, M. (2014b). Racjonalność gospodarowania finansami osobistymi. Studia Ekonomiczne, 180, 174-184.

Peć, K. (2012). Fundusze pieniężne mimo problemów lepsze od lokat. Availabled at: www. analizy.pl/fundusze/wiadomosci/12787/fundusze-pieniezne-mimo-problemow-lepsze-od-lokat.html (access: 6.02.2015).

Perez, K. (2011). Wyniki inwestycyjne funduszy hedge. Czynniki wpływające na ich interpretację. Bank i Kredyt, 42 (6), 85-124.

Perez, K. (2012). Efektywność funduszy inwestycyjnych: podejście techniczne i fundamentalne. Warszawa: Difin. 
Perez, K. (2014), Polish absolute return funds and stock funds. Short and long term performance comparison. Folia Oeconomica Stetinensia, 14 (2), 179-197. DOI: 10.1515/foli-20150016 .

Premik, F., Tyrowicz, J. (2016). Sytuacja finansowa sektora gospodarstw domowych w III kw. 2015 r., Warszawa: NBP (no. 1).

Stango, V., Zinman, J. (2009). Exponential Growth Bias and Household Finance. The Journal of Finance, 64, 2807-2849. DOI: 10.1111/j.1540-6261.2009.01518.x.

Sytuacja na rynku funduszy inwestycyjnych vs. depozyty bankowe (2016). Available at: http:// www.pkobp.pl/media_files/b9bdf699-ebfe-4605-8bdb-b3545250a3ce.pdf (access: 6.02. 2016).

www.analizy.pl (access: 6.02.2015).

www.nbp.pl (access: 6.02.2015).

www.stooq.pl (access: 6.02.2015).

Sarnowski, K. (2012). Zarządzanie finansami osobistymi w polskich instytucjach pośrednictwa finansowego. Zeszyty Naukowe Akademii Morskiej w Gdyni, 72, 16-22.

Skrobosz, M. (2014). Jak obliczyć podatek od zysków z funduszy inwestycyjnych. Available at: http://forsal.pl/gielda/artykuly/827669,jak-obliczyc-podatek-od-zyskow-z-funduszy-inwestycyjnych.html (access: 6.02.2015).

Solarz, J.K. (2010). Zarządzanie ryzykiem finansowym codzienności. Bezpieczny Bank, 3 (42), $62-79$.

Waliszewski, K. (2014). Planowanie finansów osobistych (zarządzanie finansami osobistymi) z udziałem doradców finansowych - znaczenie dla gospodarstw domowych i gospodarki. Problemy Zarzadzania, 12, (4, 48), 204-221.

Zamojska, A. (2008). An Analysis of Distribution of Rates of Return for Investment Funds Game. In: W. Milo, G. Szafrański, P. Wdowiński (eds.), Financial Markets. Principles of Modeling Forecasting and Decision-Making (pp. 163-173). Łódź: Wydawnictwo Uniwersytetu Łódzkiego.

Zamojska, A. (2012). Efektywność funduszy inwestycyjnych w Polsce: studium teoretyczno-empiryczne. Warszawa: Wydawnictwo C.H. Beck.

Zamojska, A. (2015). Zastosowanie analizy falkowej w ocenie efektywności funduszy inwestycyjnych. Prace Naukowe Uniwersytetu Ekonomicznego we Wrocławiu, 385, 325-333. DOI 10.15611/pn.2015.385.35.

Zdanowska, M. (2012). Financial capability - zdolność zarządzania finansami osobistymi. Problemy Zarządzania, Finansów i Marketingu, 21, 251-260.

Zdanowska, M. (2012). Świadomość finansowa w Polsce. Współczesne Problemy Ekonomiczne. Globalizacja. Liberalizacja. Etyka, 5, 213-225. 